\title{
Communication
}

[Comunicação]

\section{Occurrence of Contracaecum pelagicum Johnston \& Mawson 1942 (Nematoda, Anisakidae) in Sula leucogaster Boddaert 1783 (Pelecaniformes, Sulidae)}

\author{
[Ocorrência de Contracaecum pelagicum Johnston \& Mawson 1942 (Nematoda, Anisakidae) em Sula leucogaster \\ Boddaert 1783 (Pelecaniformes, Sulidae)] \\ R.J. Silva ${ }^{1}$, T.F. Raso ${ }^{2}$, P.J. Faria ${ }^{3}$, F.P. Campos ${ }^{4}$ \\ ${ }^{1}$ Departamento de Parasitologia - Instituto de Biociências - UNESP \\ Distrito de Rubião Júnior \\ 18618-000 - Botucatu, SP \\ ${ }^{2}$ Faculdade de Ciências Agrárias e Veterinária - Jaboticabal, SP \\ ${ }^{3}$ Instituto de Biociências - Universidade de São Paulo - São Paulo, SP \\ ${ }^{4}$ Fundação Florestal - Secretaria do Meio Ambiente - São Paulo, SP
}

Brazilian wildlife birds constitute a group in which the parasite-host relationship still needs to be investigated. Several studies about the identification of new parasites or about the description of new hosts have been published. The present study describes the occurrence of Contracaecum pelagicum Johnston \& Mawson 1942 (Nematoda, Anisakidae) in a new host, Sula leucogaster Boddaert 1783 (Pelecaniformes, Sulidae), species commonly known as brown-booby.

During a study on the biology of this bird species, adult and young specimens were sampled at Laje de Santos, Santos, São Paulo State, Brazil (S 24 $19^{\circ} 11^{\prime \prime}$ and W 46 $10^{\circ}$ ' 52''). When the birds were restrained by hand, an adult specimen regurgitated some nematodes. Three male and three female helminthes were collected, fixed in alcohol $70 \%$ and later clarified with phenol for morphologic and morphometric analysis in Qwin Lite 2.5 computerized system for analysis of images (Leica). All measurements refer to mean (minimum-maximum) values of the measures obtained to three males or three females.

The collected nematodes (Fig. 1) presented a strongly grooved cuticle, mouth with three lips and three interlabia, reduced ventriculus with a posterior appendix, intestinal cecum, and nerve ring. Males with two spicules of similar size, numerous pre- and post-anal papillae and absent gubernaculum. Females were didelphys, opisthodelphys, with vulva in anterior region of body. The morphometric characteristics of the males were: body with $25 \mu \mathrm{m}$ (18.8-32.7) length and $0.8 \mu \mathrm{m}(0.7-1)$ width, esophagus with $2.9 \mu \mathrm{m}$ (2.4-3.6) length, the distance from the nerve ring to the anterior extremity was $0.5 \mu \mathrm{m}$ (0.4-0.6), the ventriculus appendix presented $0.8 \mu \mathrm{m}(0.7-0.9)$, the intestinal caecum measured $2.0 \mu \mathrm{m}$ (1.7-2.4), spicules with 4.0 $\mathrm{m}$ (3.3-4.9) length, and the distance from the cloaca to the posterior end was $0.2 \mu \mathrm{m}(0.1-0.2)$. The males also presented seven pairs of post-anal papillae. The females presented body with $16.6 \mu \mathrm{m}$ (11.323) length and $0.5 \mu \mathrm{m}(0.3-0.7)$ width, esophagus with $2.1 \mu \mathrm{m}$ (1.6-2.8) length, the distance from the nerve ring to the anterior extremity was $0.4 \mu \mathrm{m} \quad(0.3-0.5)$, the ventriculus appendix presented $0.6 \mu \mathrm{m} \quad(0.5-0.7)$, the intestinal caecum measured $1.5 \mu \mathrm{m}$ (1.1-1.9), the distance from the vulva to the anterior extremity was $5.9 \mu \mathrm{m}(3.9-8.5)$, and the distance from the anus to the posterior end was $0.2 \mu \mathrm{m}(0.1-0.3)$.

Recebido para publicação em 3 de fevereiro de 2004

Recebido para publicação, após modificações, em 13 de agosto de 2004

E-mail: reinaldo@ibb.unesp.br 

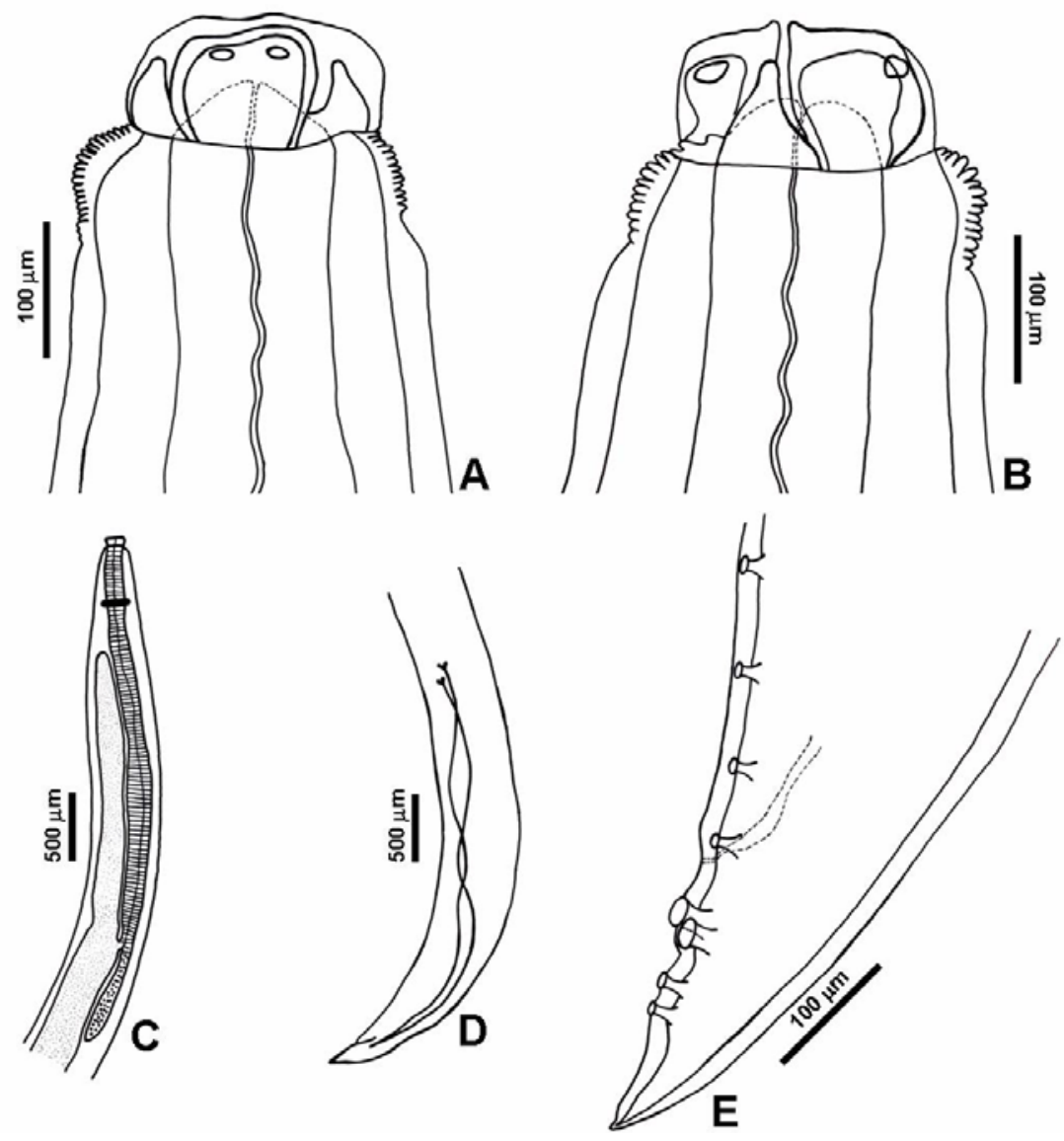

Figure 1. Contracaecum pelagicum (Nematoda, Anisakidae) from Sula leucogaster (Pelecaniformes, Sulidae): A) Cephalic extremity, dorsal view; B) Cephalic extremity, ventral view - Note in A and B the lips and interlabia; C) Anterior extremity; D) Male posterior extremity - note the spicules; E) Male posterior extremity - note papillae from lateral side of this region.

The morphologic analysis allowed to conclude that the species involved in the parasitism was $C$. pelagicum (Johnston and Mawson, 1942). This is the first report in the literature on the occurrence of nematodes of the genus Contracaecum in $S$. leucogaster. This report is important because few studies exist on the host species of these helminthes. In the case of C. pelagicum, there are only three reports in the literature on the occurrence of this species in birds. The hosts mentioned in these papers are Diomedea melanophris (Johnston and Mawson, 1942; Lent and Teixeira de Freitas, 1948), D. chlororhynchos (Johnston and Mawson, 1942) and Spheniscus magellanicus (Santos, 1984). All those birds live in environments that are similar to that of $S$. leucogaster and all are piscivorous, thus susceptible to infection by $C$. pelagicum through the ingestion of fish infected with larvae of these nematodes (Knoff et al., 2001).

It should also be mentioned that the collected specimens of $C$. pelagicum were not completely developed. The measures of the males and of the females were very variable. However, the species was identified mainly based on the number and position of the pre- and post-anal papillae of the males. The observed characteristics agree with the description of this species (Johnston and Mawson, 1942; Lent and Teixeira de Freitas, 1948; Santos, 1984; Vicente et al., 1995).

Keywords: brown-booby, Sula leucogaster, pelecaniformes, Contracaecum pelagicum, Nematoda, new host 


\section{RESUMO}

Relata-se a ocorrência de Contracaecum pelagicum Johnston \& Mawson 1942 (Nematoda, Anisakidae) em um novo hospedeiro, Sula leucogaster Boddaert 1783 (Pelecaniformes, Sulidae), espécie conhecida como atobá. Três machos e três fêmeas dessa espécie de nematódeo foram coletados no regurgito da ave. Pela análise morfológica conclui-se que C. pelagicum era a espécie envolvida no parasitismo. Este é o primeiro relato sobre a ocorrência de nematódeos do gênero Contracaecum em $\mathrm{S}$. leucogaster.

Palavras-chave: atobá, Sula leucogaster, pelecaniformes, Contracaecum pelagicum, Nematoda, novo hospedeiro

\section{REFERENCES}

JOHNSTON, T.H.; MAWSON, P.M. Nematodes from Australian albatrosses and petrels. Trans. R. Soc. S. Aust., v.66, p.66-70, 1942.

KNOFF, M.; SÃO CLEMENTE, S.C.; PINTO, R.M.; GOMES, D.C. Nematodes of elasmobranch fishes from the southern coast of Brazil. Mem. Inst. Oswaldo Cruz, v.96, p.81-87, 2001.

LENT, H.; TEIXEIRA DE FREITAS, J.F. Uma coleção de nematódeos, parasitos de vertebrados, do
Museu de História Natural de Montevideo. Mem. Inst. Oswaldo Cruz, v.46, p.1-71, 1948.

SANTOS, C.P. Um nematódeo parasita do pingüim Spheniscus magellanicus (Forster) (Ascaridoidea, Anisakidae). Mem. Inst. Oswaldo Cruz, v.79, p.233237, 1984.

VICENTE, J.J.; RODRIGUES, H.O.; GOMES, D.C.; PINTO, R.M. Nematóides do Brasil. Parte IV: Nematóides de aves. Mem. Inst. Oswaldo Cruz, v.12, suppl.1, p.1-273, 1995. 